\title{
Peter Ivanič
}

\section{Christianization of the Territory of Today's Moravia and Slovakia before $863^{1}$}

\section{Pokristjanjevanje ozemlja današnje Moravske in Slo- vaške pred letom 863}

Abstract: Christianization, associated with consolidation of power and establishment of early Christian state formations, contributed significantly to creation of medieval Europe. Although the territory of today's Moravia (eastern part of the Czech Republic) and Slovakia came into contact with Christianity already at the end of antiquity, the more intensive Christianization of these lands took place only from the $8^{\text {th }}$ century, when this territory was settled by Slavs. Missionaries from the Frankish Empire, from the territory of Istria, Dalmatia and northern Italy came here. Domestic Slavic elites started to convert to Christianity as from the $9^{\text {th }}$ century. For them, Christianity became a means of recognizing their social status externally and allowed them to integrate with the more culturally advanced Christian world. Archaeological findings (e.g. crosses and captorgs, plaques and bells from Bojná, objects of secular character), written sources, sacral architecture and burying methods testify to the existence of Christianity in the territory of today's Moravia and Slovakia, especially in centers of the power.

Key words: christianization, Christianity, missionaries, Slovakia, Moravia

Povz̧etek: Pokristjanjevanje, povezano z utrjevanjem oblasti in vzpostavljanjem zgodnjih krščanskih državnih tvorb, je odločilno prispevalo k oblikovanju srednjeveške Evrope. Čeprav je ozemlje današnje Moravske (vzhodnega dela današnje Češke republike) in Slovaške prišlo v stik s krščanstvom že ob koncu antike, se je intenzivnejše pokristjanjevanje omenjenih dežel dogajalo šele od 8. stoletja naprej, ko so to ozemlje naselili Slovani. Tja so prihajali misijonarji iz Frankovskega cesarstva, Istre, Dalmacije in severne Italije. Domače slovanske elite so se v 9. stoletju začele spreobračati v krščanstvo. Zanje je krščanstvo pomenilo sredstvo zunanje podkrepitve njihovega družbenega položaja in jim

1 The survey was elaborated within the VEGA Project No. 1/0006/18 „Imago Episcopi-Power of a Bishop and its Presentation in the Middle Ages". This work was supported by the Slovak Research and Development Agency under the contract No. APVV16-0116 „Study of Byzantine Value System and its Reflection in Slavic Cultural Environment". 
je omogočilo vključitev v kulturno razvitejši krščanski svet. O navzočnosti krščanstva na ozemlju današnje Moravske in Slovaške, zlasti v središčih oblasti, pričujejo arheološke najdbe (npr. križi in kaptorgi, plošče in zvonovi iz Bojne, predmeti posvetnega značaja), pisni viri, sakralna arhitektura in načini pokopavanja mrtvih.

Ključne besede: pokristjanjevanje, krščanstvo, misijonarji, Slovaška, Moravska

\section{Introduction}

Christianization, associated with consolidation of power and establishment of early Christian state formations, contributed significantly to creation of medieval Europe (Berend 2007). Although the intense Christianization of the Central European area began in the early Middle Ages, the territory of today's Moravia (eastern part of the Czech Republic) and Slovakia came into contact with Christianity already at the end of antiquity. Evidence of presence of Christianity in the area north of the Danube dates back to the Roman Empire. By the end of the first century, the Roman Empire acquired the territory of Raetia, Noricum and Pannonia under its rule. The origins of Christianity in this area are usually associated with presence of Roman legionaries who stayed here in the $2^{\text {nd }}$ century (Harreither 1999, 6-45). In addition to legionnaires, people, especially merchants who moved along the famous Amber Road directly from Aquileia, where there was one of the first Christian communities in the north of Italy, could also bring Christian ideas in the area. Individual routes of the Amber Road also crossed the territory of Slovakia and Moravia. Spreading of Christianity in the area of Noricum and Pannonia started to gain realistic features only in the $3^{\text {rd }}$ century (Kolník 2001, 51-92). From the well-preserved sources, we know that several prominent church leaders were born in Pannonia (Anthony of Lérins, St. Martin of Braga). Christian communities existed in the Carpathian Basin and also outside the territory of the Roman Empire. Arian Christianity spread among the Goths who moved from the lower Danube to Transylvania. There were several missionaries among them. The most famous was Wulfila (Ulphilas), of Gothic origin, who was consecrated in 341 as a bishop for Christians living in the Danube region. He translated the New Testament and the Lord's Prayer into the gothic language in 369. His translation played an important role in the spread of Arian Christianity among the Germanic ethnic groups (e.g. Goths, Vandals, Rugians, Heruli, Gepids). Unique finding of fragments of Wulfila's translation of the Lord's Prayer and the Gospel according to John was discovered in the burial place in Hács-Béndekpuszta (Somogy County) from the 5th and 6th century which is located near the Lake Balaton in today's Hungary. These texts were preserved on lead panels. Written sources from the $7^{\text {th }}$ century mention that the Avars, who came to the Danube region after 568, took prisoners from Balkan or northern Italy who were Christian from their successful military campaigns to the territory of the Avar Khaganate. Avars became an important power in the territory of the Danube region, however no ecclesiastical organiza- 
tion was established on their territory by the end of the $8^{\text {th }}$ century. The Avar elites converted to Christianity only under the threat of military expeditions from the Frankish Empire (Vida 2016, 93-105). More intensive Christianization of Moravia and Slovakia thus took place only from the $8^{\text {th }}$ century, when this area was settled by Slavs.

\section{Christianization of Moravia and Slovakia before 828 and its reflection in written sources}

The activity of Christian missionaries in Central Europe in the $8^{\text {th }}$ and $9^{\text {th }}$ centuries is evidenced by a limited number of written and archaeological sources. Written sources mention the missions of St. Martin of Tour and St. Amandus among the Slavic people before this period (Bartoňková and Večerka 2010, 32-37), but more significant missionary activity occurred after the victorious campaign of the Frankish Empire against the Avars at the end of the $8^{\text {th }}$ century. A congregation of bishops on the banks of the river Danube (Conventus episcoporum ad ripas Danubii) was carried in 796. It was organized by Pepin, the son of Frankish king Charles the Great (742/747-814, the king since 768, the emperor since 800). In addition to the Bavarian bishops, the Patriarch Paulinus II of Aquileia (787-802/804) also took part. This congregation discussed Christianization of the territory gained from the Avars. It is apparent from the record that even before that date there was an intensive but disorganized spread of Christian faith in the Avar-dominated territory. The written source mentions a need to verify, whether the baptized people of the conquered country were baptized in the name of St. Trinity. The written source also defines specific rules for baptism. We learnt from the Aquileian record of the synod that in 796 there were predicatores illius terre ${ }^{2}$ divided into three groups by Paulinus according to the way of baptism. The first were priests - sacerdotes who baptized in the name of the Holy Trinity, which was also to be examined; but their baptisms should have been valid. The second were ,clerics', who baptized with the water blessed by the priest in the name of the Holy Trinity; their baptisms did not need to be repeated, but for completeness of the baptism, the baptisms were to undergo a ceremony of hands imposition. The third group were uneducated clerics - clerici illiterati, who baptized by soaking in water, without the Confession of Faith and without a full trinitarian formula, it means without a notice of Jesus Christ. As far as according to the orthodox view, unblessed water without the Holy Spirit has no spiritual effect in baptism, such baptisms should not apply. Baptism was to be held in groups on Easter (Pascha) and Pentecost (Pentecosten), and only exceptionally on Sundays. The priest was supposed to prepare catechumens for two days or more weeks, while the catechumens had

2 This term is interpreted differently in the literature. Peter Ratkoš $(1971,74)$ assumes that the term ,predicatores illius terre' means missionaries in the land of Avars (and Slavs). In the source edition of Magnae Moraviae fontes historici (Bartoňková and Večerka 2013,6) it is explained in the note that they were priests from Pannonia. 
to observe a seven-day Lent before the baptism (Bartoňková and Večerka 2013, $5-7)$. In addition to questions of the sacraments, problems related to the ecclesiastical organization were discussed during the Synod. Apparently, Pepin assigned a part of Lower Pannonia to the clerical administration of Arno, the Bishop of Salzburg, to spread Christianity among the Avars and Slavs. It was confirmed in writing by Charles the Great in $803(2011,304)$. On the basis of information on the Synod in 796, an important Czech art historian Josef Cibulka assumed that part of the inhabitants of Pannonia, who were subject to Avars, were Christians in the second half of the $8^{\text {th }}$ century or even earlier (Cibulka 1958, 175). He claimed that the Christians mentioned in the report from the Synod were Slavs living in Pannonia. In his opinion, it is evident from this information that the Moravian Slavs were neighbors of Christian Slavs from Pannonia in the second half of the $8^{\text {th }}$ century (176). The Slovak historian Rastislav Kožiak $(2006,138-139)$ emphasizes that in this period Christians were searched for among descendants of the Romanized population who survived in isolation in some parts of Pannonia. To lesser extent, they were also descendants of Christian prisoners. In case of the Slavs, he thinks that Christianity penetrated only among the elites in the border areas of Longobard and later in the Franconian regions.

The document Conversio Bagoariorum et Carantanorum mentions that the Bishop of Salzburg, Arno, as well as his predecessor Virgil (745-784), sent priests to the territory of Carinthia and Lower Pannonia. In the opinion of Josef Cibulka $(1958,176)$, the activities of these clergy were focused only on Slavs. The important Slovak medievalist Richard Marsina $(1995,114-115)$ believes that Christianity in the Middle Ages began to spread sporadically before the end of the $8^{\text {th }}$ century in the territory of Slovakia. In his opinion, Christian missionaries were supposed to come to us irregularly and for a short time already in the $7^{\text {th }}$ century and certainly in the $8^{\text {th }}$ century. The situation changed after several defeats of the Avar Khaganate by Charles the Great and at the turn of the 8th and 9th century, there was already more intensive Christianization in the territory of today's Slovakia. Peter Ratkoš $(1971,75)$ assumed that the mission centers for activities between the Avars and the Slavs were Aquitaine, Salzburg, or his Carinthian archipresbyterial center Maria Saal, or Passau and Benedictine monasteries Kremsmünster, Mondsee and Niederalteich.

An important event from the point of view of Christianization of Western Slavs was the promotion of the Bishopric of Salzburg to the Archbishopric, which was carried out by Charles the Great in 798 with consent of the Pope. The first archbishop Arno (the bishop from 784 and archbishop from 798 to 821) was given a task to establish a spiritual administration of the regions where the Slavs lived (Cibulka 1958, 176).

In connection with the missions, it is also necessary to mention a decision of the Emperor Charles the Great in 811 in the dispute between the Patriarch of Maxenti and the Archbishop of Salzburg Arno (784-821) on the borders of two provinces. The Emperor decided that the border of their activity was the Dráva River (Bartoňková and Večerka 2013, 19). According to Vladimír Vavřínek (1963, 
39), although the Aquileian expansion to the north was limited, but it did not alter the activity of its clergy in Pannonia. As an example, he mentions the church of St. John the Baptist in Récéskút near Zalávar which originates in Dalmatia according to the architectural space arrangement.

Synods in 794 in Frankfurt am Main and in 813 in Mainz were also important for Christianization of Western Slavs. The acts of the Frankfurt Synod include the point 42, where it is stated that the God can be glorified in all languages and not only in three (Bartoňková and Večerka 2013, 3). The acts of the Mainz Synod allow the newly baptized to learn the confession of faith and the Lord's Prayer in their own language (15-17). Based on the existing knowledge in the field of linguistics, it can be assumed that even before arrival of St. Constantine-Cyril and Methodius to Great Moravia, there were shorter Christian texts (e.g. Confession of the Faith (Credo), The Lord's Prayer) in the local form of the Slavonic language. These are associated with missions from the Frankish Empire. Well-known are confessional prayers written in the Latin alphabet which are also called Freising manuscripts. Christian terms such as oplatъ (Holy wafer), m๖ša or križb penetrated the Slavonic environment (Čermák 2013, 55).

\section{Christianization of Moravia and Slovakia between 828 and 863}

The first written mention of the sacral building in the territory of Slovakia can be found in the chronicle Conversio Bagoariorum et Carantanorum which originated in Salzburg between 870-871 and it highlights the contribution of the Salzburg Archbishops to Christianization of the Slavic population living in the territory of Pannonia. The mention about the Pribina fortress built on the river Zala (today's Hungary) and on consecration of the church of St. Mary The Mother of God in Blatnohrad contains a parenthesis that the Salzburg Archbishop Adalram (821836) consecrated the church at the place called Nitrava (Bartoňková and Večerka 2011, 273) on the property of the Prince Pribina behind the Danube. Conversio Bagoariorum et Carantanorum does not mention when this event occurred and for whom the temple was built in addition to Pribina. Josef Cibulka (1933, 34-35) did not comment on dating of this event in his work Great Moravian Empire, but he doubted that the temple was built for the people of Pribina. He rather assumed that it was rather built for Christian foreigners (merchants, foreigners, military organizers). Another option mentioned by the author were German (Frankish author's note) Christian merchants in the service of Pribina. He justified it by consecration by Salzburg Archbishop. Another hypothesis presented by the author was that Pribina annexed a principality in which Christians already lived. He also did not exclude a possibility that the church was built for the rest of Christians living here before arrival of the Slavs. The Slovak historian Daniel Rapant (1941/1942, 20-21) took a stand on these theories and he linked construction of the church to Pribina's wife, who, in his opinion, came from the Bavarian and the- 
refore Christian environment. In his monograph Great Moravian Church in Modrá near Velehrad and the beginnings of Christianity in Moravia Josef Cibulka (1958, 252-257) devoted a short chapter to the issue of the church in Nitra. Here, he commented on dating of this event. In his opinion, it happened in 828. It was based on the assumption that the Archbishop of Salzburg Adalram participated in the military campaign of Louis the German against the Bulgarians. He also visited Nitra on this occasion. This dating was also adopted by other authors. It is also worth mentioning here the opinion of Heinz Dopsch $(1978,14)$ and Herwig Wolfram $(1979,30 ; 1995,323)$, who dated the consecration of the church to 828 upon agreement between the Bishop of Passau Reginhar (818-838) and the Archbishop of Salzburg Adalram from 829, according to which they divided the area east of the Vienna Forest. The territory north of the Danube, it means also Moravia and Slovakia should belong to Passau. However, Ján Steinhübel $(1995,18 ; 2004,79)$ questions a right of Salzburg to the Upper Pannonia. He points out that the deed of 829 , which was confirmed by the King Louis, the German did not create a new ecclesiastical administration, but confirmed the original state of it. In his opinion, the mutual boundaries of the Passau and that time Salzburg diocese were to be agreed during the Synod in 796. Richard Marsina (1995, 116-117) believes that the religious building in Nitra consecrated by Adalram was the church of the Christianization mission, which was then active in the princely seat of the Principality of Nitra. The brick churches in the newly-Christianized territories were established only after a more developed degree of Christianity was reached, when the ecclesiastical organization began to develop in the respective territory. For this reason, the church from 828 could, in his opinion, be the seat of the chief priest, Archipresbyter, who was the head of Christianization in the Principality of Pribina. At the time of the consecration of the church, the chief priest of Nitra was a direct subordinate to the Archbishop of Salzburg and to the Bishop of Passau after 829.

A question of Pribina's church localization in Nitra remains unanswered. It was assumed in older literature that it is a chapel with a horseshoe chevet in today's sacral complex at the Nitra Castle. This opinion was eliminated by the archeological survey of the Czech monument man and architect Václac Mencl carried out in 1930-1931. Younger archaeological researches at the Nitra Castle confirmed the existence of several buildings that can be dated back to the $9^{\text {th }}$ century. It was possible to document the mortar remains in several places of the Castle hill, a block of lithothamnium limestone and a fragment of a capping decorated with a plant motif. A similar fragment was found in the church tower. Based on existing knowledge, there were at least three buildings at the Castle before the middle of the $11^{\text {th }}$ century (Fusek and Bednár 2006, 39-44; Ivanič 2008, 60-69). According to Alexander Ruttkay $(2000,628-630)$, architectural articles are likely to have a Carolingian character and testify to the existence of a sacral building before the middle of the $9^{\text {th }}$ century. The Czech archaeologist Zdeněk Měřinský $(2006,136)$ states that the church was certainly located in the area of the Nitra Castle, because the continuity and tradition of the place, which later became a bishopric, must be taken into account. A reason why the church consecrated in 828 has not been 
discovered yet by the archaeological research is probably a fact that the space where it was probably built was covered by later buildings and apparently also destroyed by building activities and landscaping (Hanuliak 2019, 77).

There is a mention in the Records of Passau Bishops that the Passau Bishop Reginhar (818-838) baptized all Moravians in 831 (Havlík et al. 1969, 407). According to Vladimír Vavř́nek $(1963,44)$, this statement cannot be understood literally, because a large proportion of Moravians were baptized before and on the other hand, not all Moravians were Christians. In his opinion, at this time the Bishop of Passau took over the ecclesiastical administration of Great Moravia and started to organize more intense and organized Christianization. On the other hand, Czech historian Dušan Třestík (2001, 120-121) considered this information to be relatively reliable, because it fits perfectly in the overall situation of Moravia at that time. Richard Marsina $(1995,117)$ considers that an archipresbyterate could be established in Moravia this year.

The Mainz Synod was held in 852. It also dealt with the case of Albigis, who kidnapped a wife of a man named Patrik and run away to the country of Moravians. It is specifically written about "rudis adhuc christianitas gentis Maraensium « (Bartoňková and Večerka 2013, 33-35). Based on this sentence it can be assumed that Moravian Christianity was still imperfect (Cibulka 1958, 283). ${ }^{3}$ It is also considered that common people outside the central or princely castles could still worship pagan gods during this period (Vavrínek 2002, 305).

From the perspective of Christianization of Moravia and Slovakia, a question of church organization before arrival of the Cyril-Methodius mission in Moravia and Slovakia is interesting. Vladimír Vavrínek (1963a, 45-48) stated that in the first half of the $9^{\text {th }}$ century the Bishop of Passau built an archipresbyterate, which meant the first firm arrangement of ecclesiastical conditions. According to his opinion, there was a school at the seat of the archipresbyter the task of which was to provide theological education of domestic pupils and their preparation for priests. The Slovak historian Peter Ratkoš $(1971,79-80)$ came to conclusion that in the middle of the $9^{\text {th }}$ century there were up to four archipresbyteriates in Great Moravia, while he referred to the mention of dioceses in Great Moravia from $899 / 900$. One was to be based in Nitra. He stated that there was also lower ecclesiastical organization within the Bishopric of Passau (archipresbyterian parishes) in Great Moravia, and he also presumed parish archipresbyterian schools where priests were educated. Richard Marsina $(1995,118)$ assumes a dualist politicaladministrative organization for Great Moravia. It means two archipresbyteriates - one based in Nitra and the other in Moravia. After establishment of such an ecclesiastical organization, a school could be established, where students could continue their studies in the Archbishop's seminary in Salzburg and also in Passau after 829. He considers the appointment of archipresbyters to be the third phase of Christianization of this territory. Luděk Galuška (2017, 225-226) assumes a spontaneous Christianization for the territory of Moravia in the first third of the

3 V. Vavřínek (1963a, 48-49) points to the survival of pagan customs in burial grounds. 
$9^{\text {th }}$ century, while the ecclesiastical organization was to be established consequently under the leadership of the Bishops of Passau who established the archipresbyriate. In his opinion, the archipresbyter of the Bishop of Passau could reside in the so-called the three-aisled basilica (church No. 3) in Mikulčice, which was built in the first half of the $9^{\text {th }}$ century and it was the largest sacral building in Moravia at that time.

\section{Origin of missionaries}

In connection with Christianization of Slovakia and Moravia, it is necessary to mention the origin of the first missionaries. Based on the finding of foundations of the church in Modrá na Morave, Josef Cibulka $(1958,199-233)$ tried to prove the presence of the Irish (Irish-Scotish) mission in Great Moravia and he dated the church to the beginning of the $9^{\text {th }}$ century. His publication provoked a sharp discussion in the scientific circles of that time, while most scientist opposed this theory (Graus 1959, 479-483; Vavrínek 1959, 217-224). Nevertheless, this theory found also some supporters (Dittrich 1962, 41-53; Lacko 1991, 66-70; Lichardus $2003,109-118)$. It is possible to distinguish several problematic issues in connection with Irish influences at the Slavs. First of all, the direct involvement of monks in Christianization is problematic. The second problem is the Irish influence on church institutions in Slavic countries. Finally, the third problem is the presumed presence of monks from the islands in the Slavic area - it means searching for people of Irish origin among the clergy (Boron 2007, 60-73). In addition to the aforementioned architecture, the presence of the term inokostb in the Old Slavonic language, which means peregrination and was taken from the language of Irish monks, was mentioned as another proof of the presence of Irish influences in Moravia (Mareš 1964, 7-11). From Slovak researchers, the issue of Irish missions was compiled in more details by Rastislav Kožiak (2004, 103-124), who expressed rather skeptically on possible operation of this mission in the CentralEastern part of Europe based on the existing known sources. The origins of Christianity in Slovakia and Moravia are connected with Frankish hegemonic politics. Based on written and archaeological sources, Vladimír Vavř́nek (1959, 217-224) came to conclusion that missionaries from Bavaria and the Dalmatian-Istrian region were active in the territory of the later Great Moravia in the early $9^{\text {th }}$ century. In his opinion, clergymen of the latter area had to subordinate themselves to the ecclesiastical organization created by the Bishopric of Passau. The written source Žitije Mefodija (Bartoňková and Večerka 2010,144) contains a remark that many teachers: Christians from Vlachs (Romance-speaking lands), Greece and Germany came to Moravia who taught differently. In case of missionaries from Germany, it is clear that the authors meant the clergy of the Frankish Empire. The remark about missionaries from Vlachs and Greek was more discussed in the literature. The Czech Byzantinist Vladimír Vavř́nek (1963b, 471-477) hypothetically assumed that these missionaries came from the Dalmatian-Istrian region, 
which was under the ecclesiastical administration of the Patriarchate of Aquileiain the first half of the $9^{\text {th }}$ century. He explained this by the fact that Latin and Greek cultures blended together in this area, and that is why both Greek and Italian clergymen were probably from this area. He pointed to the mention of the Danube Synod, where the Aquilian Patriarch Paulinus II was also invited. He completely ruled out a possibility of a mission of teachers from Greece directly organized by Byzantium. It was supported by archaeological findings, which do not show more lively contacts between Byzantium and Moravia. The Moravian medievalist Lubomir Emil Vilém Havlík (1970, 118-119) pointed out that the Grado Patriarchate maybe participated in the missionary activity in Moravia, and thus exactly this area could be meant under the name Vlachs, less likely than Aquileia. He states that Venice was also included under the administration of the Grado Patriarchate. In this connection, he states that the probable journey of Constantine and Methodius to Moravia maybe led through Venice; he also mentions their later stay in the city. He also mentions here John of Venice, the priest and the diplomat. He assumed that in this mention Greece meant a Grecized territory of southeastern Europe belonging to the Constantinople Patriarchate and it probably was Dalmatia. On the contrary, the Slovak Byzantinist Alexander Avenarius (1992, 61-62) understood the region of Istria, Dalmatia and northern Italy under the term Vlachs. In case of missionaries from Greece, he supported a theory that this meant the territory of the Dalmatian and Istrian coasts where the Latin language was used, although this area was under the administration of Byzantium. ${ }^{4}$

\section{Evidence of Christianization in archaeological findings}

Archaeological findings testify to the existence of Christianity in the territory of the present-day Moravia and Slovakia, especially at centers of power. Evident proof of the Christianity presence are the remains of sacral buildings. Archaeological and architectural researches confirmed that most churches were built before arrival of the Byzantine mission of St. Constantine-Cyril and Methodius to Great Moravia in 863 (e.g. Břeclav-Pohansko, Basilica at Bratislava Castle, Modrá pri Velehrade, Mikulčice-church No. 2, Staré Město-Na Valách and Na Špitálkach, Uherské Hradiště-Sady). The question of origin of sacral buildings in Moravia and Slovakia is often discussed in historiography. Opinions are not uniform. In general, patterns for this kind of constructions are sought in the Frankish Empire and the Northern Italian and Adriatic regions (Botek 2014; Galuška 2017, 233-243).

The presence of Christians in Moravia and Slovakia is also evidenced by burial methods at burial grounds. The Slavs originally buried by cremation. At the turn of the $8^{\text {th }}$ and $9^{\text {th }}$ century, inhumation prevailed in Moravia. The placement of a deceased in a coffin is considered one of the most important features of Christi-

With regard to the supposed missionary activities in Moravia and Slovakia from several areas, it should be noted that there were already differences between the Byzantine tradition and the West in that time, for example in wedding ceremony (Saje 2018, 813-823; 2019, 989-1000). 
anity. The most documented cases of this type of burying come from the most important centers in Moravia - Mikulčice, Staré Město and Uherské Hradiště. The oldest cases are dated back to the first half of the $9^{\text {th }}$ century. They are characterized by the fact that they contain grave equipment. However, there is no grave equipment in such graves from the younger period (Galuška 2017, 243-248). The situation in Slovakia is more complicated. Based on the findings, Milan Hanuliak assumes the presence of coffins in graves at the burial grounds in Bíňa-Hospodářský dvůr, Ducové, Michal nad Žitavou, Nitra-castle hill, while he dates only $8 \%$ of cases to the older phase of Great Moravian period. However, he does not express to the fact, whether the individuals buried in this way can be considered Christians (Hanuliak 2004, 95-96).

Activity of the Christian missions before arrival of the St. Constantine-Cyril and Methodius in Great Moravia are connected with findings from Slovakia, specifically from the hillfort Bojná I.-Valy. It is a set of four circular pieces and two plaques in shape of a rounded isosceles cross and three wrought frames. Figures with wings were embossed on circles and plaques. Two exemplars were decorated with letters. It is assumed that these findings were part of a portable altar-reliquary the origin of which can be found in the Patriarchate of Aquileia. In addition, one bronze bell and two fragments of bells were discovered on the site. These findings are dated back to the first half of the $9^{\text {th }}$ century. Bells belong among the oldest findings of its kind in Europe (Hanuliak and Pieta 2014, 144-145; Pieta and Ruttkay, 2006, 21-70).

Crosses or captorgs found at archeological sites from the period of Great Moravia are also a clear symbol of Christianity. Findings of a silver cast cross with the image of Christ and lead processionary from Mikulčice in Moravia are well-known. Their origin was assumed in the Syrian-Egyptian region and they were dated back to the period before arrival of the missionaries - St. Constantine-Cyril and Methodius in Great Moravia (in 863). Currently, their domestic production is not excluded and both artifacts together with other crosses from this site are dated to the second half of the $9^{\text {th }}$ century. Lead crosses are known from several locations in the Lower Moravian region which are divided into several types (Brenhardsthal, Dolní Věstonice, Velké Bílovce, Mutěnice and Windegg), but their occurrence dates back to the late $9^{\text {th }}$ or early $10^{\text {th }}$ century. These types of crosses are associated with Bavarian missions or directly with the activities of the Bishopric of Passau after expulsion of Methodius pupils (in 885) that focused their attention to countryside (Kouril 2014b, 102-113). Findings from Slovakia dated before the end of the $8^{\text {th }}$ century include a bronze cross from Dolné Orešany. The encolpion cross from Vel'ká Mača, which is included among Byzantine products of Syrian-Palestinian origin is one of the most famous artefact (Hanuliak and Pieta 2014, 138-142).

The remnant of a box made of wood on which metal parts in the shape of a cross were preserved was found in a man's grave near the church No. 3 in Mikulčice (grave no. 300). It is assumed that this artefact is a late imitation of pyxides produced in the Eastern Mediterranean or the Balkan-Adriatic region. Based on the pigeon sculpture and the concept of cross-shaped decoration, it is 
associated with Christian ideology. It is believed that the box came to Moravia as a liturgical object (personal reliquary) in the form of a gift before middle of the $9^{\text {th }}$ century (Kavánová 2014, 114-117).

Christianity can be also associated with objects of a profane character (e.g. belt fittings, sword sheath, earrings, spurs) on which the Christian symbol is applied (Roganský 2009).

\section{Conclusion}

In conclusion, the inhabitants living in the territory of today's Moravia (eastern part of the Czech Republic) and Slovakia came into contact with Christianity already at the end of antiquity, but more intense Christianization of this area took place mainly from the end of the $8^{\text {th }}$ century from the territory of Frankish Empire. It is evidenced by written and archeological sources, as well as by sacral architecture. Domestic Slavic elites started to convert to Christianity as from the $9^{\text {th }}$ century. As stated by Rastislav Kožiak (2004, 145), for them Christianity became a means of recognizing their social status externally and allowed them to integrate with the more culturally advanced Christian world. Arrival of the Byzantine mission of St. Constantine-Cyril and Methodius in 863 and their activities mean the next phase of Christianization of Slavs in Moravia and Slovakia, characterized by introduction of the Old Slavonic language into the liturgy, the translation of worship books into this language, establishment of a school for education of priests, implementation of Christian legal order and also establishment of an independent ecclesiastical organization under the protection of the Roman Pontifical See. Their mission has had an important ecumenical significance as can be in both the Roman and Greek Catholic, as well as the Protestant environments. Traces of their theological legacy can be found in the current ecumenical teaching on the Trinity (Valčo 2017) but also in individual protestant theologians, such as Martin Chemnitz (Valčo 2019). Besides a distinct theological legacy, their mission experience served as a precursor and, in some instances, a template for personal piety (Tirpák 2018) or setting up a workable relationship between the Church and the State (Šoltés 2017).

\section{References}

Avenarius, Alexander. 1992. Byzantská kultúra v slovanskom prostredí v VI. -XII. storoči: K problému recepcie a transformácie. Bratislava: Veda.

Bartoňková, Dagmar, and Radoslav Večerka, eds. 2010; 2011; 2013. Magnae Moraviae fontes historici. Vol. 2, Textus biographici, hagiographici, liturgici. Vol. 3, Diplomata, epistolae, textus historici varii. Vol. 4, Leges textus iuridici supplementa. Prague: KLP.
Berend, Nora, ed. 2007. Christianization and the Rise of Christian Monarchy: Scandinavia, Central Europe and Rus' c. 900-1200. Cambridge: Cambridge University Press.

Boroń, Piotr. 2007. Iroscottish Attempts to Christianize the Slavs: Sources and Myths of historiography. In: Duchovné, intelektuálne a politické pozadie cyrilometodskej misie pred jej príchodom na Vel'kú Moravu, 60-73. Nitra: UKF. 
Botek, Andrej. 2014. Vel'komoravské kostoly na Slovensku a odraz ich tradície v neskoršom období. Bratislava: Post Scriptum.

Cibulka, Josef. 1933. Pribina a jeho kostol v Nitre. In: Ján Stanislav, ed. Ríša vel'komoravská: Sborník vedeckých prác, 25-52. Prague: L. Mazáč.

- - - 1958. Velkomoravský kostel v Modré u Velehradu a začátky křestáanství na Moravě. Prague: Nakladatelství ČSAV.

Čermák, Václav. 2013. Staroslověnské písemníctví cyrilometodějské a jeho rukopisné dochovaní [Cyrillo-Methodian Old Church Slavonic Literature and Its Manuscripts Tradition]. In: Cyril a Metoděj-doba, život, dilo [Cyril and Methodius - Their Era, Lives, and Work], 55-68. Brno: Moravské zemské muzeum.

Dittrich, Zdenek Radslav. 1962. Christianity in Great-Moravia. Groningen: J. B. Wolters.

Dopsch, Heinz. 1978. Salzburrg und der Südosten. Südostdeutsches Archiv 21:5-35.

Fusek, Gabriel, and Peter Bednár. 2008. Die (vermutete) Kirche am Burgberg von Nitra. In: Martina Pippal and Falko Daim, eds. Frühmittelalterliche Wand Malereien aus Mähren und der Slowakei. Archäologischer Kontext und herstellungstechnische Analyse, 39-44. Innsbruck: Univ.-Verl. Wagner.

Galuška, Luděk. 2017. Slované - stopy předků: O Moravě v 6. - 10. století. Brno: Moravské zemské museum.

Graus, František. 1959. K počátkům křestáanství na Moravě. Československý časopis historický 7, no. 3:479-483.

Hanuliak, Milan. 2004. Vel'komoravské pohrebiská. Pochovávanie v 9. - 10. storočí na území Slovenka. Nitra: AÚ SAV.

- - - 2019. Štruktúra vel'komoravského hradiska mesta Nitrava na základe pochovávania [The Structure of Castle Town Nitrava Based on Interments]. In: Hradiská - svedkovia dávnych čias 2: Zborník príspevkov o hradiskách a ich obyvatel'och, 75-89. Dolná Mariková: Občianske združenie Hradiská - Slovensko.

Hanuliak, Milan, and Karol Pieta. 2014 Ninth Century Movable Material Evidence of Christianisation in the Eastern Parts of Great-Moravia. In: Kouřil 2014a, 138-151.

Harreither, Reinhard. 1999. Frühes Christentum am österreichischen Donaulimes. In: Frühes Christentum am österreichischen Donaulimes, 6-45. Vienna: Institut für Klassische Archäologie.

Havlík, Lubomír E. 1970. Učitelé-křestané z Vlach i z Řecka a z Němec. In: Sborník Jozefu Poulíkovi k šedesátinám, 117-120. Brno: Archeologický ustav ČSAV.
Havlík, Lubomír Emil, Dagmar Bartoňková, Ivan Hrbek, Jaroslav Ludvíkovský and Radoslav Večerka. 1969. Magnae Moraviae Fontes Historici. Vol. 3, Diplomata, epistolae, textus historici varii. Brno: Universita J.E. Purkyně.

Ivanič, Peter. 2008. Pribinov kostol v Nitre v zrkadle historiografie. Konštantínove listy 1:60-69.

Kavánová, Blanka. 2014. Reconstruction of the Reliquary from Mikulčic. In: Kouřil 2014a, 114-119.

Kolník, Titus. 2001. Kontakty raného krestáanstva s územiami strednej Európy vo svetle archeologických a historických prameňov. Studia archaeologica Slovaca mediaevalia 3-4:51-92.

Kouřil, Pavel, ed. 2014a. The Cyril and Methodius Mission and Europe: 1150 Years Since the Arrival of the Thessaloniki Brothers in Great Moravia. Brno: Archeologický ústav AV ČR.

Kouřil, Pavel. 2014b. Archaeological Evidence of Christianity in Relics of Material Culture of the 9th and 10th Centuries in Moravia with Focus on Crosses. In: Kouřil 2014a, 102-113.

Kožiak, Rastislav. 2004. Írski misionári a počiatky krest́anstva u Slovanov v stredovýchodnej Európe. In: Rastislav Kožiak and Jaroslav Nemeš, eds. Pohanstvo a krestáanstvo, 103-124. Bratislava: Chronos.

- - - 2006. Christianizácia Avarov a Slovanov na strednom Dunaji: Príbeh svätcov-misionárov, svätá vojna alebo kultúrny šok? In: Rastislav Kožiak and Jaroslav Nemeš, eds. Svätec a jeho funkcie v spoločnosti. Vol. 1, 121-147. Bratislava: Chronos.

Lacko, Michal. 1991. Svätí Cyril a Metod. Rome: Slovenský ústav sv. Cyrila a Metoda.

Lichardus, Jozef. 2003. Grundriss einer Altslawischen Holzkirche von Modrá. Slovenská archeológia 51, no. 1:109-118.

Mareš, František Václav. 1964. Stopa předcyrilometodějských moravských misii iroskotských v česko-staroslovenskěslovné zásobě? Vznik $a$ počatky Slovanů 5:7-11.

Marsina, Richard. 1995. Začiatky cirkevnej organizácie na Slovensku (od prelomu 8./9. až do začiatku 11. storočia). Slovenská archivistika 30, no. 2:113-126.

Měřínsky, Zdeněk. 2006. České země od příchodu Slovanů po Velkou Moravu. Vol 2. Prague: Libri.

Pieta, Karol, and Alexander Ruttkay. Bojná: mocenské a christianizačné centrum Nitrianskeho kniežatstva; Predbežná správa [Bojná: Neues Macht und christianisierungszentrum des Fürstentums von Nitra; Vorbericht]. In: Karol Pieta, Alexander Ruttkay and Matej Ruttkay, eds. Bojná: Hospodárske a politické centrum 
Nitrianskeho kniežatstva [Wirtschaftliches und politisches Zentrum Nitraer Fürstentums], 21-70. Nitra: AÚ SAV - Ponitrianske múzeum .

Ratkoš, Peter. 1971. Kristianizácia Vel'kej Moravy pred misiou Cyrila a Metoda. Historický časopis 19, no. 1:71-83.

Roganský, Lukáš. 2009. Signa Christiana: artefakty krest'anského rázu z poslednej tretiny prvého tisícročia medzi Čechami a Potisím. Nitra: UKF v Nitre.

Ruttkay, Alexander T. 2000. Neutra (Nitra) und Zobor. In: Alfried Wieczorek and Hans-Martin Hinz, eds. Europas Mitte um 1000 Beiträge zur Geschichte, Kunst und Archäologie: Handbuch zur Ausstellung. Vol. 1, 628-630. Stuttgart: Konrad Theiss Verlag.

Saje, Andrej. 2018. Vpliv poročnih praks starih kultur na sklepanje zakona prvih kristjanov [Influence of Wedding Customs of Old Cultures on the Contracting of Marriage of First Christians]. Bogoslovni vestnik 78, no. 3:813-823.

- - - 2019. Sklepanje krščanskega zakona na Zahodu in Vzhodu od pozne antike do zgodnjega srednjega veka [Celebration of Christian Marriage in the West and East from the Late Roman to the Early Medieval Period]. Bogoslovni vestnik 79, no. 4:989-1000. https://doi. org/10.34291/bv2019/04/saje

Steinhübel, Ján. 1995. Vel'komoravské územie v severovýchodnom Zadunajsku. Bratislava: Veda.

- - - 2004. Nitrianske kniežatstvo: Počiatky stredovekého Slovenska. Budmerice: Rak.

Šoltés, Radovan. 2017. Pohl'ad sociálnej náuky Cirkvi na úlohu a význam štátu. Theologos 19, no. 2:132-142.

Tirpák, Peter. 2018. Význam náboženského putovania v živote Cirkvi. Theologos 20, no. 1:91-98.

Třestík, Dušan. 2001. Vznik Velké Moravy: Moravané, Čechové a Střední Evropa v letech 791871. Prague: NLN.

Valčo, Michal. 2017. Chemnitz's Eucharistic Christology as an Impulse for Ecumenical Dialogue between East and West. Konstantinove Listy 10, no. 2:141-150. https://doi.org/10.17846/ cl.2017.10.2.141-150

- - . 2019. Ecumenical Trinitarian Reflections and the ,De Régnon Paradigm': A Probe into Recovering the Social-Trinitarian Emphases of the Cappadocian Fathers. Constantine's Letters 12, no. 1:76-89. https://doi.org/10.17846/ cl.2019.12.1.76-89

Vavřínek, Vladimír. 1959. K otázke počátků christianisace Velké Moravy. Listy filologické 82:217-224.

- - - 1963a. Cirkevní misie v dějinách Velké Moravy. Prague: Lidová demokracie.
- - . 1963b. Předcyrilometodějské misie na Velké Moravě (k výkladu 5 . kapitoly staroslověnského života Metodějova). Slavia 32, no. 4:465480.

-- - 2000. Mission in Mähren: Zwischen dem lateinischen Westen und Byzanz. In: Alfried Wieczorek and Hans-Martin Hinz, eds. Europas Mitte um 1000 Beiträge zur Geschichte, Kunst und Archäologie. Handbuch zur Ausstellung. Vol. 1, 304-310. Stuttgart: Konrad Theiss Verlag.

Vida, Tivadár. 2016. Christianity in the Carpathian Basin during Late Antiquity and the Early Middle Ages (5th to 8th century AD). In: Endre Tóth, Tivadar Vida and Imre Takács, eds. Saint Martin and Pannonia: Christianity on the Frontiers of the Roman World, 93-106. Pannonhalma: Pannonhalmi Foapátság-Savaria Múzeum.

Wolfram, Herwig. 1979. Conversio Bagoariorum et Carantanorum: Das Weissbuch der Salzburger Kirche über die erfolgreiche Mission in Karantanien und Pannonien. Graz: Hermann Böhlaus Nachf.

-- - 1995. Salzburg, Bayern, Österreich: Die Conversio Bagoariorum et Carantanorum und die Qullen ihrer Zeit. Wien: R. Oldenbourg Verlag. 